Article

\title{
The Influence of $\mathrm{NaCl}$ and Glucose Content on Growth and Ochratoxin A Production by Aspergillus ochraceus, Aspergillus carbonarius and Penicillium nordicum
}

\author{
Yan Wang ${ }^{1} \mathbb{D}$, Hao Yan ${ }^{2, *}$, Jing Neng ${ }^{1}$, Jian Gao ${ }^{3}$, Bolei Yang ${ }^{3}$ and Yang Liu ${ }^{4, *}$ \\ 1 College of Food science and Technology, Zhejiang University of Technology, Hangzhou 310014, China; \\ wangyan062006@zjut.edu.cn (Y.W.); nengjing@zjut.edu.cn (J.N.) \\ 2 Zhejiang Provincial Center for Disease Control and Prevention, Hangzhou 310051, China \\ 3 Institute of Food Science and Technology, Chinese Academy of Agricultural Sciences, Beijing 100193, China; \\ gaojian_2020@126.com (J.G.); yangbolei@caas.cn (B.Y.) \\ 4 School of Food Science and Engineering, Foshan University, Foshan 528231, China \\ * Correspondence: hyan@cdc.zj.cn (H.Y.); liuyangg@hotmail.com (Y.L.)
}

Received: 22 June 2020; Accepted: 5 August 2020; Published: 12 August 2020

check for updates

\begin{abstract}
Ochratoxin A (OTA) is a nephrotoxic mycotoxin, which deserves particular attention for its widespread contamination of a variety of food and feed. Aspergillus ochraceus, Aspergillus carbonarius, and Penicillium nordicum are an important source of OTA in three different kinds of food commodities, including cereals, grape and dried fruit products, and dry-cured meat products. Deeper knowledge of OTA production and mycelium growth related to the high-sugar or $\mathrm{NaCl}$-rich environments was gained in this manuscript. A. ochraceus and P. nordicum were likely to have greater growth rates in medium supplied with certain concentrations of $\mathrm{NaCl}(0-80 \mathrm{~g} / \mathrm{L})$, and the colony diameter was the largest at the salt content of $40 \mathrm{~g} / \mathrm{L}$. P. nordicum was more suitable to grow in $\mathrm{NaCl}$-riched medium, the OTA production was increased to $316 \mathrm{ppb}$ from $77 \mathrm{ppb}$ when $20 \mathrm{~g} / \mathrm{L} \mathrm{NaCl}$ was added. The capability of OTA production was inhibited when salt content was $40 \mathrm{~g} / \mathrm{L}$ and $60 \mathrm{~g} / \mathrm{L}$ in A. ochraceus and $P$. nordicum, respectively. As the glucose content increased to $250 \mathrm{~g} / \mathrm{L}$, the capacity of mycelium growth and sporulation was increased significantly in A. ochraceus and A. carbonarius. A. carbonarius was more suitable to grow in high-sugar grape products. OTA production was significantly promoted with an added $100 \mathrm{~g} / \mathrm{L}$ glucose in $A$. carbonarius. OTA production was inhibited when glucose content was $150 \mathrm{~g} / \mathrm{L}$ and in $200 \mathrm{~g} / \mathrm{L}$ in A. ochraceus and A. carbonarius, respectively. $\mathrm{NaCl}$ and glucose have an effect on fungal growth and OTA production, and the activation of biosynthetic genes of OtaA. These results would allow designing new strategies to prevent OTA accumulation on sugar or NaCl-riched foodstuffs and achieve the objective to manufacture cereals, dried vine fruits and dry-cured ham, free of OTA.
\end{abstract}

Keywords: ochratoxin A; A. ochraceus; A. carbonarius; P. nordicum; NaCl-riched; high-sugar

Key Contribution: OTA production was inhibited when salt content was $40 \mathrm{~g} / \mathrm{L}$ and $60 \mathrm{~g} / \mathrm{L}$ in A. ochraceus and $P$. nordicum, respectively. OTA production was inhibited when glucose content was $150 \mathrm{~g} / \mathrm{L}$ and in $200 \mathrm{~g} / \mathrm{L}$ in A. ochraceus and A. carbonarius, respectively. The maximum of OTA production was in $P$. nordicum with $20 \mathrm{~g} / \mathrm{L} \mathrm{NaCl}$, and in A. carbonarius with $100 \mathrm{~g} / \mathrm{L}$ glucose. By controlling $\mathrm{NaCl}$ addition, the content of glucose concentration and monitoring the expression of toxigenic genes, the aim was to reduce colonization and toxin production. 


\section{Introduction}

Ochratoxin A (OTA) is a nephrotoxic mycotoxin, which deserves particular attention as it is a widespread toxin in various contaminated foods and types of feed. Because of the temperature and humidity preferences, ochratoxigenic Aspergillus and Penicillium occur mainly on food commodities like cereal (Aspergillus ochraceus, Aspergillus westerdijkiae, Penicillium verrucosum), coffee (Aspergillus steynii, Aspergillus sclerotioniger), grapes, wine and dried fruits (Aspergillus carbonarius, Aspergillus niger, A. ochraceus), cheese and dry-cured meat products (Penicillium nordicum) [1,2]. OTA is inevitably ingested by human beings and animals as a result. A great deal of animal or cell experiments have reported that the OTA exposure can cause nephrotoxicity, hepatotoxicity, immunotoxicity, genotoxicity and other toxicological effects [3]. OTA was classified as a group 2B carcinogen by the International Agency for Research on Cancer (IARC) in 1993.

A. ochraceus, A. carbonarius and P. nordicum are believed to be important sources of OTA in food commodities [2]. Ochratoxin A production is in relation to water activity and temperature [4]. A. ochraceus and closely related species grow under moderate temperatures at low water activities [5]. They are mostly associated with dried and stored foods, especially cereal and coffee. Black Aspergilli, mainly A. carbonarius, are considered as the primary source of OTA on grapes and similar fruits produced on the berries during the growing season, mainly from maturing to ripening in sunlight at high temperatures [6-8]. In the traditional meat products with long maturity periods, especially in fermented meat products, toxigenic moulds are mainly comprised of Aspergillus and Penicillium spp., which often overgrow [9]. P. nordicum is adapted to $\mathrm{NaCl}$ rich environments like salt rich dry-cured meat products, cheeses or even salines [10]. On the contrary, A. carbonarius frequently exists in sugar rich substrates like grapes and grape juices, which is another environment with high concentrations of solutes different from $\mathrm{NaCl}$ rich environments [11].

The decrease in water activity ensures the microbial stability and safety of food products. High concentrations of solutes, e.g., in $\mathrm{NaCl}$ rich substrates like ham and cheeses, or in sugar rich substrates like grapes and grape juices, not only decrease the water activity of the substrate, but also provoke osmotic stress, affecting the adaptation of this specific fungal population and toxin production [10-12]. OTA biosynthesis is in charged of a gene cluster, which contains four highly conserved biosynthetic genes (otaA-D) and a bZIP transcription factor (otaR1). A pathway-specific regulator, OtaR1, controls OTA production by regulating the four OTA biosynthetic genes [13]. Polyketide synthase OtaA is the first limited enzyme in the synthesis of OTA. Halogenation by the halogenase OtaD is the last step of the synthesis of OTA, and the chloride ion is related to substitution reaction $[13,14]$. The biosynthesis of ochratoxin A by Penicillium is considered as one mechanism for adaptation to $\mathrm{NaCl}$ rich foods [15].

Thus, further studies are required to fully understand the advantageous adaptation of A. ochraceus, A. carbonarius, and P. nordicum in high concentrations of solutes, and their ability to produce OTA. The aim of this study was to adapt different concentrations of salt solution and sugar solution to determine simultaneously the effects on the growth and OTA production and the high concentration solution on the OTA biosynthesis gene expression in A. ochraceus, A. carbonarius, and P. nordicum. The aim of this work was to evaluate the influence of exogenous $\mathrm{NaCl}$ or glucose on mycelial growth rate and expression levels of OTA biosynthetic genes in relation to OTA production; the results would allow designing new strategies to prevent OTA accumulation on ham, cheese, grape juice and so on, achieving the goal to manufacture food free of OTA.

\section{Results}

\subsection{The Colony Morphology Are Affected by High Concentration of NaCl or Glucose}

To investigate the influence of high osmotic conditions on growth and spore production, different concentrations of $\mathrm{NaCl}(0,20,40,60,80,100 \mathrm{~g} / \mathrm{L})$ or glucose $(0,50,100,150,200,250 \mathrm{~g} / \mathrm{L})$ were added into medium. The colony morphology was observed for $24 \mathrm{~h}$ to $108 \mathrm{~h}$ after incubation. 
There was no significant change in colony morphology and colony color at high osmotic conditions (Figure 1).

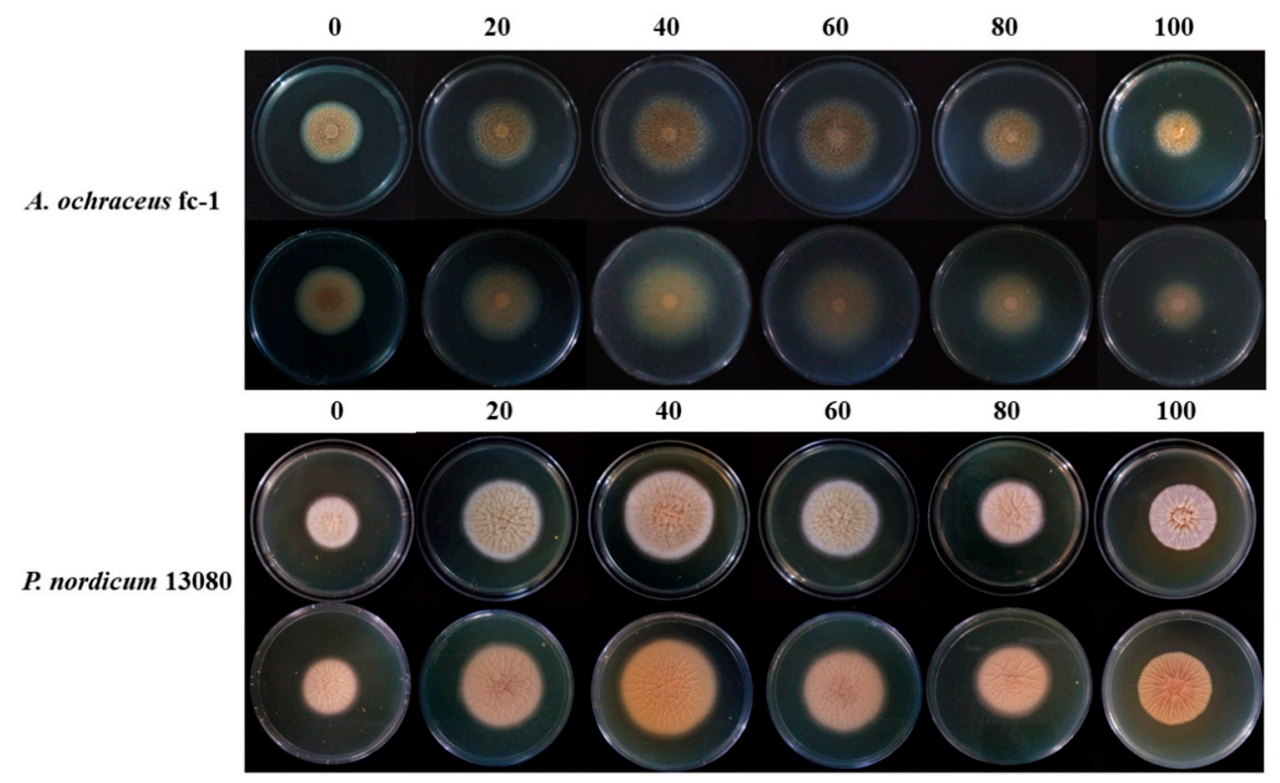

(A)

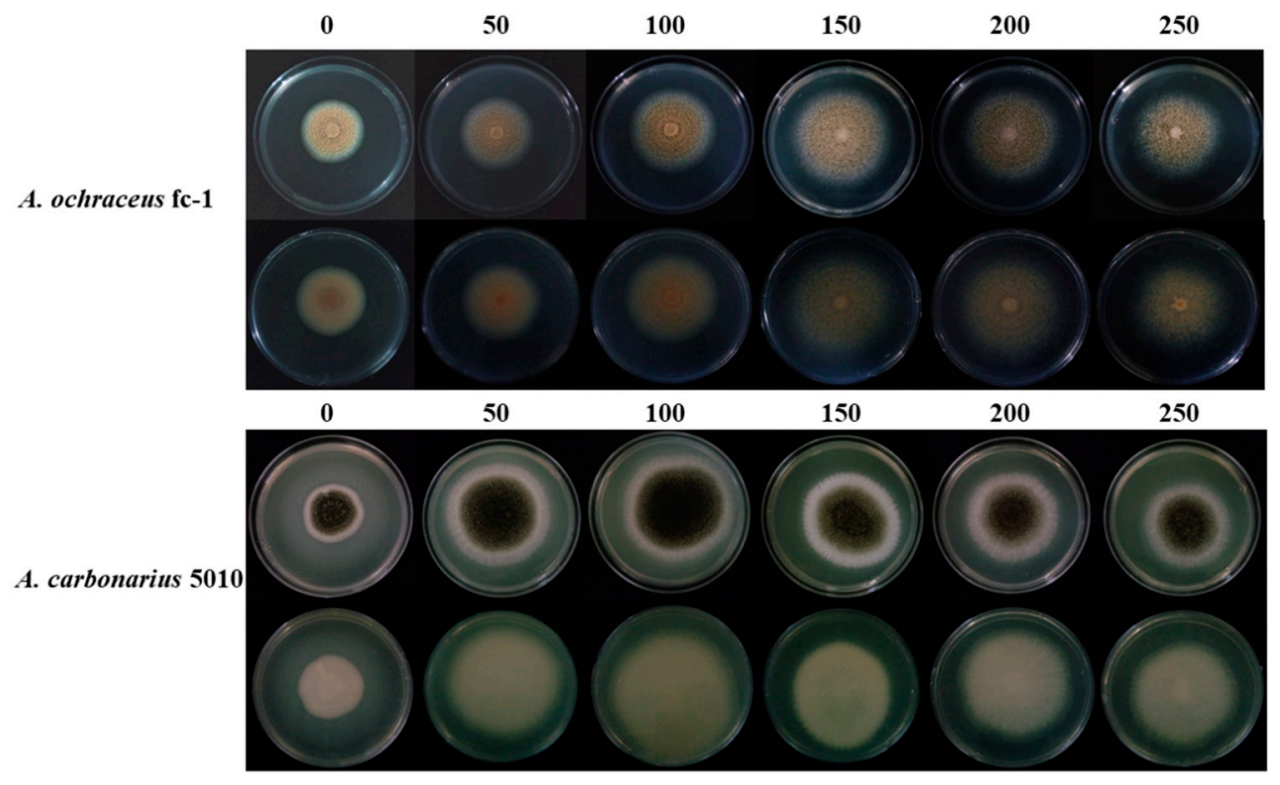

(B)

Figure 1. The colony of A. ochraceus fc-1, A. carbonarius 5010, P. nordicum 13080 after 4 days of incubation at $28{ }^{\circ} \mathrm{C}$ : (A) Colonies of $A$. ochraceus $f_{c}-1$ grown on $0,20,40,60,80,100 \mathrm{~g} / \mathrm{L} \mathrm{NaCl}$-supplemented Potato Dextrose Agar (PDA) plates. Colonies of P. nordicum 13080 grown on NaCl-supplemented Malt Extract Agar (MEA) plates. (B) Colonies of A. ochraceus $f_{c}-1$ grown on 0, 50, 100, 150, 200, $250 \mathrm{~g} / \mathrm{L}$ glucose-supplemented PDA plates. Colonies of A. carbonarius 5010 grown on glucose-supplemented Yeast Extract Sucrose Agar (YES) plates.

The mycelial growth rates are clearly affected by high osmotic conditions (Figure 1). With the increase in $\mathrm{NaCl}$ concentration, the growth of hyphae showed a trend of first strengthening and 
then weakening. Low concentrations of $\mathrm{NaCl}$ promoted the growth of A. ochraceus fc-1 (Figure 2A). When $40 \mathrm{~g} / \mathrm{L} \mathrm{NaCl}$ was added, the diameter of the colony was $40.3 \%$ larger than that of the control group without $\mathrm{NaCl}$. When $80 \mathrm{~g} / \mathrm{L} \mathrm{NaCl}$ was added, the growth rate of mycelia was weakened during the first two days of culture. When $100 \mathrm{~g} / \mathrm{L} \mathrm{NaCl}$ was added, the diameter of the colony was $7.9 \%$ smaller than that of the control group without $\mathrm{NaCl}$ (Figure $2 \mathrm{~A}$ ).

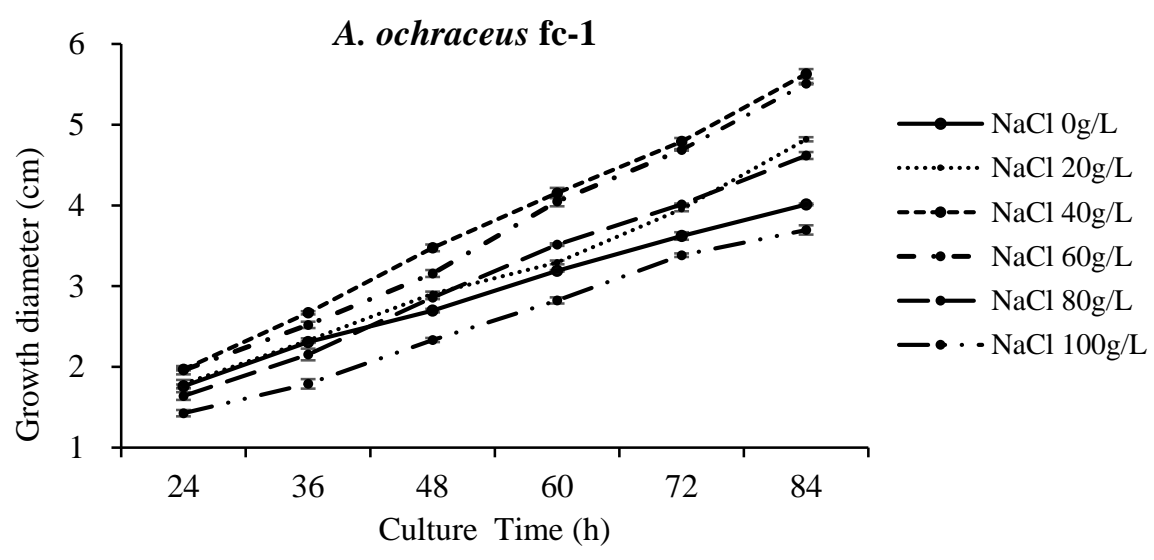

(A)

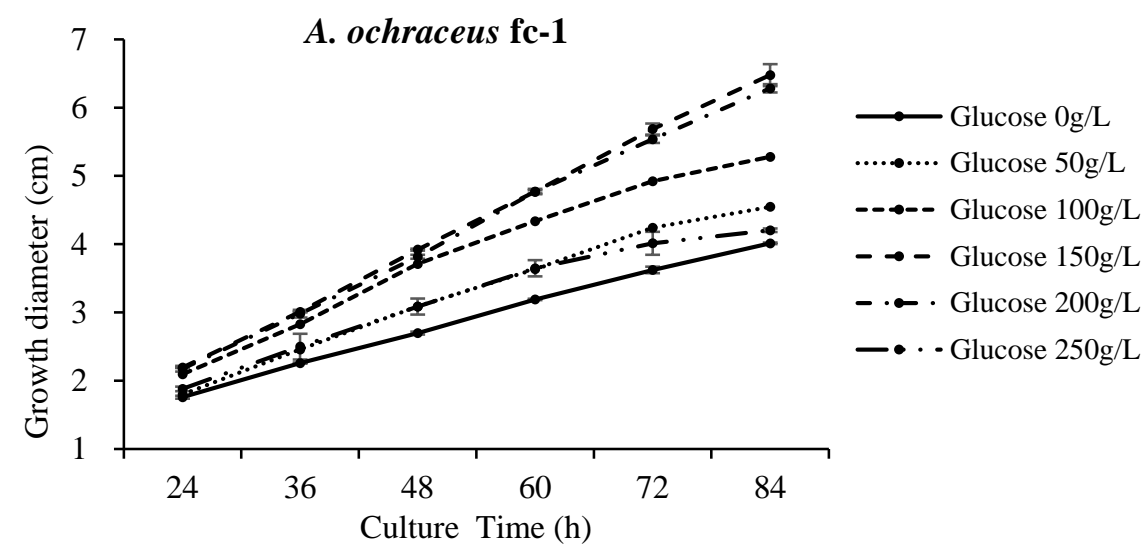

(B)

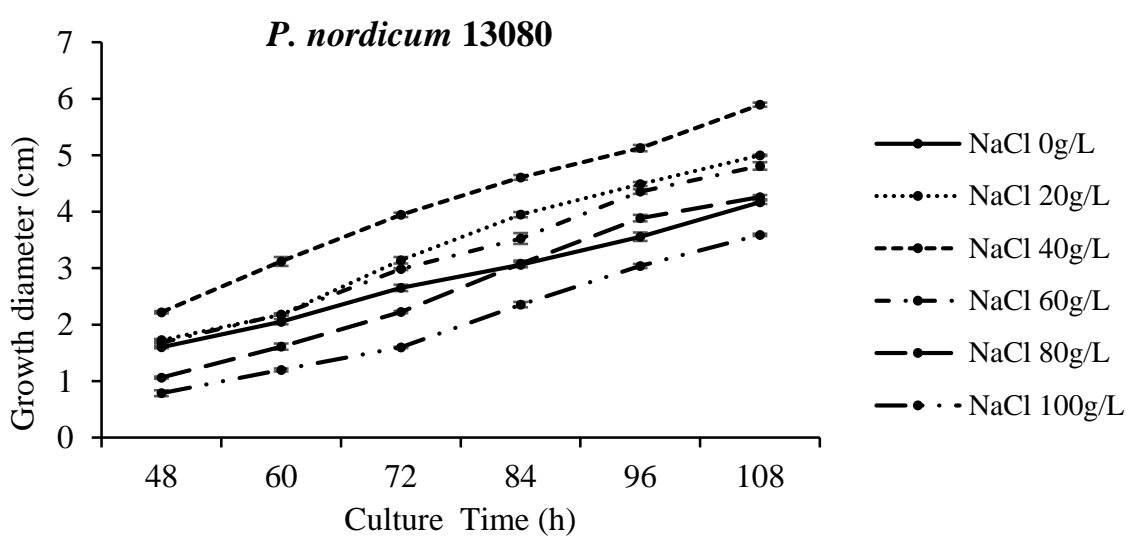

(C)

Figure 2. Cont. 


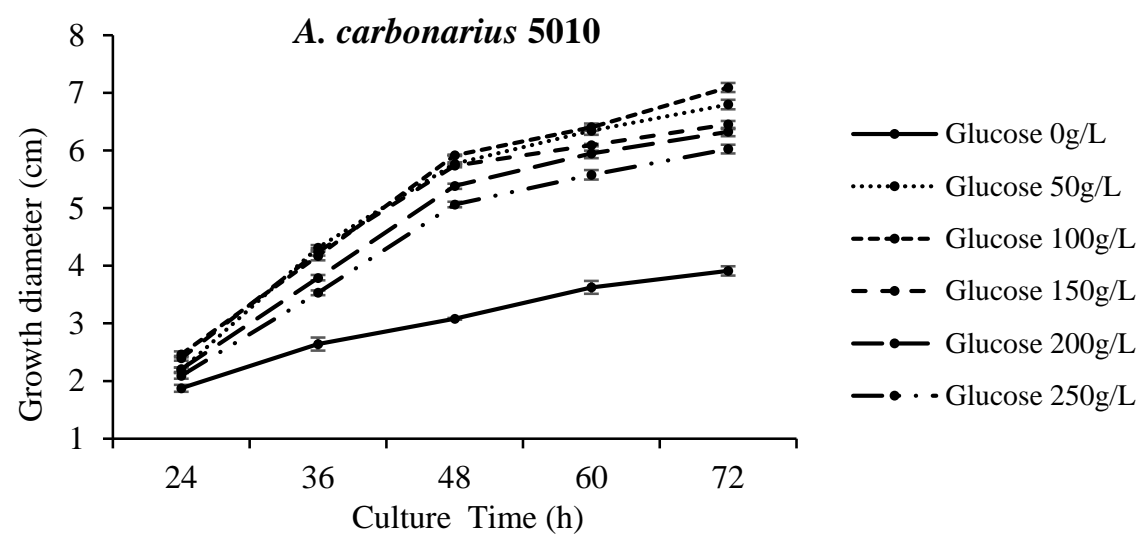

(D)

Figure 2. The colony diameter of A. ochraceus fc-1, A. carbonarius 5010, P. nordicum 13080 after 4 days of incubation at $28{ }^{\circ} \mathrm{C}$ : (A) The colony diameter of $A$. ochraceus fc-1grown on $\mathrm{NaCl}$-supplemented PDA plates at different culture times; (B) The colony diameter of A. ochraceus fc-1grown on glucose-supplemented PDA plates at different culture times; (C) The colony diameter of $P$. nordicum 13080 grown on $\mathrm{NaCl}$-supplemented MEA plates at different culture times; (D) The colony diameter of A. carbonarius 5010 grown on glucose-supplemented YES plates at different culture times.

With the addition of glucose at 0-200 g/L, the growth of hyphae was gradually accelerated (Figure 2B). With the addition of $150 \mathrm{~g} / \mathrm{L}$ glucose, the growth rate of hyphae was the highest. The colony diameter was $61.4 \%$ larger than that of the control group without glucose. With the addition of $250 \mathrm{~g} / \mathrm{L}$ glucose, the growth rate of mycelia was weakened, while the colony diameter was still $4.8 \%$ larger than that of the control group (Figure 2B).

The effect of $\mathrm{NaCl}$ on P. nordicum 13080 is consistent with A. ochraceus fc-1 (Figure 2C). Low concentrations of $\mathrm{NaCl}$ promoted the growth of P. nordicum 13080. When $40 \mathrm{~g} / \mathrm{L} \mathrm{NaCl}$ was added, the diameter of the colony was $41.4 \%$ larger than that of the control group without $\mathrm{NaCl}$. When $80 \mathrm{~g} / \mathrm{L}$ $\mathrm{NaCl}$ was added, the growth rate of mycelia was reduced during the first three days of the culture; however, the growth rate of mycelia was still $2.2 \%$ larger than that of the control on the fifth day. When $100 \mathrm{~g} / \mathrm{L} \mathrm{NaCl}$ was added, the diameter of the colony was $13.9 \%$ smaller than that of the control group without $\mathrm{NaCl}$ (Figure 2C).

Glucose promoted the mycelial growth of $A$. carbonarius 5010 significantly more than that of $A$. ochraceus fc-1 (Figure 2D). Among the addition of glucose at $0-250 \mathrm{~g} / \mathrm{L}$, the growth of hyphae was significantly accelerated compared to the control without glucose. With the addition of $100 \mathrm{~g} / \mathrm{L}$ glucose, the growth rate of hyphae was the highest. The colony diameter was $81.4 \%$ larger than that of the control group without glucose (Figure 2D).

\subsection{The Spore Production Are Affected by High Concentration of $\mathrm{NaCl}$ or Glucose}

When the concentration range was $0-40 \mathrm{~g} / \mathrm{L} \mathrm{NaCl}$ for the culture of $A$. ochraceus fc- 1 , the capacity of spore producing was improved (Figure 3A). When the concentration range was greater than $60 \mathrm{~g} / \mathrm{L}$ $\mathrm{NaCl}$, the spore-producing capacity was reduced significantly. When $80 \mathrm{~g} / \mathrm{L} \mathrm{NaCl}$ was added, the spore production was $61.4 \%$ of the control group without $\mathrm{NaCl}$ (Figure $3 \mathrm{~A}$ ). With the addition of glucose at the concentration range of $0-250 \mathrm{~g} / \mathrm{L}$, the spore-producing capacity could be improved to different degrees (Figure 3B). When $150 \mathrm{~g} / \mathrm{L}$ glucose was added, the spore-producing capacity was strongest and the spore production was $70.5 \%$ larger than that of the control group without glucose (Figure 3B). 
A. ochraceus fc-1

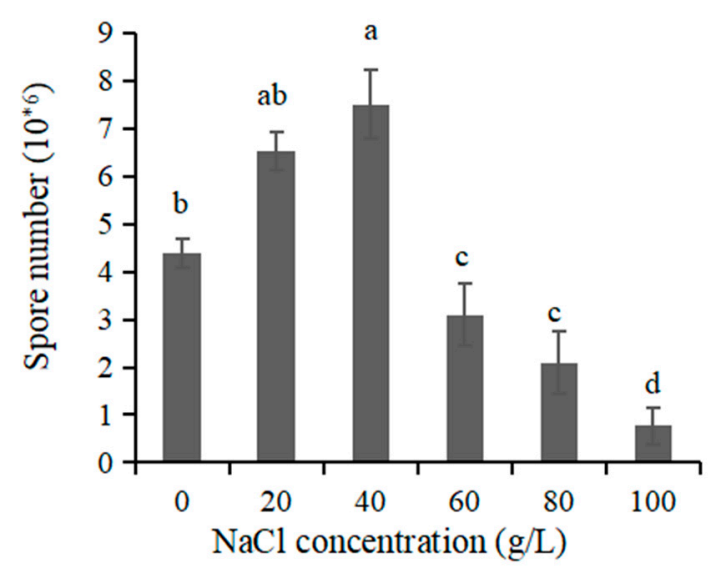

(A)

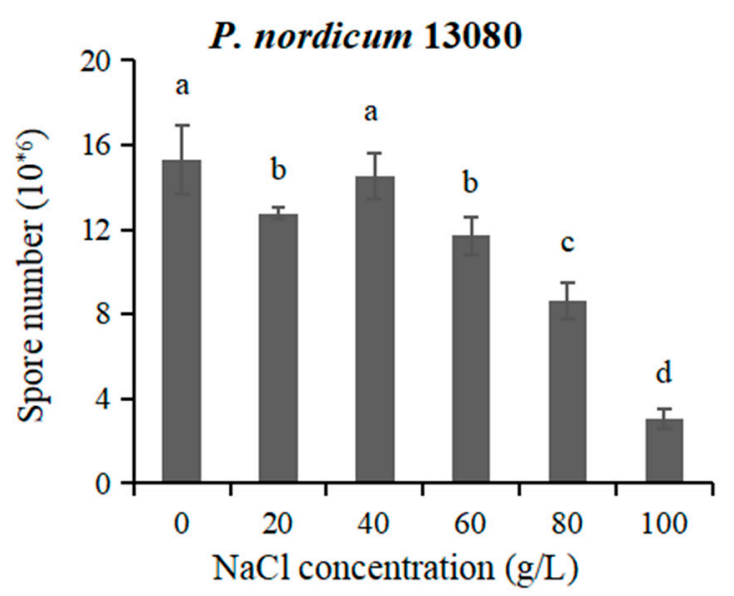

(C)

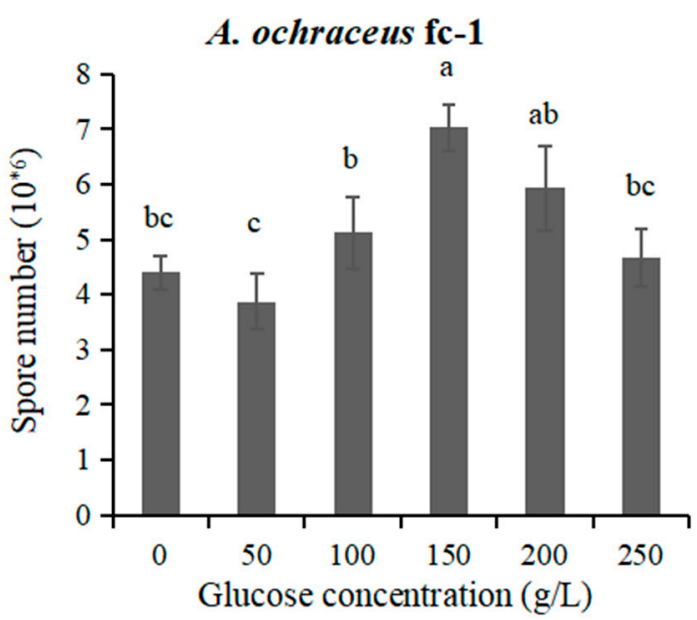

(B)

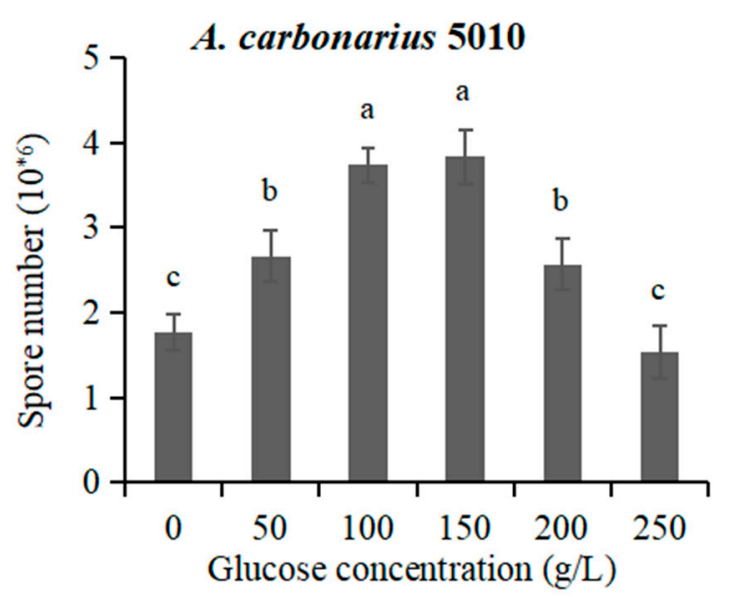

(D)

Figure 3. Spore production of A. ochraceus fc-1, A. carbonarius 5010 and P. nordicum 13080. (A) Spores were collected from $A$. ochraceus fc-1grown on 0, 20, 40, 60, 80, $100 \mathrm{~g} / \mathrm{L} \mathrm{NaCl-supplemented} \mathrm{PDA} \mathrm{plates;}$ (B) Spores were collected from A. ochraceus fc-1grown on 0, 50, 100, 150, 200, $250 \mathrm{~g} / \mathrm{L}$ glucose-supplemented PDA plates; (C) Spores were collected from P. nordicum 13080 grown on NaCl-supplemented MEA plates; (D) Spores were collected from A. carbonarius 5010 grown on glucose-supplemented YES plates. Different letters indicate a significant difference between the corresponding values $(p<0.05)$.

With the addition of $\mathrm{NaCl}$, the spore-producing capacity of the P. nordicum 13080 decreased to different degrees. When $80 \mathrm{~g} / \mathrm{L} \mathrm{NaCl}$ was added, the spore production was $42.6 \%$ lower than that of the control group without $\mathrm{NaCl}$ (Figure 3C).

With the addition of glucose at the concentration range of $0-200 \mathrm{~g} / \mathrm{L}$, the spore-producing capacity could be improved to different degrees (Figure 3D). When $250 \mathrm{~g} / \mathrm{L}$ glucose was added, the spore production was slightly lower than that of the control. With the addition of $150 \mathrm{~g} / \mathrm{L}$ glucose, the spore-producing capacity was the strongest. The spore production was 2.17 times larger than that of the control group without glucose (Figure 3D).

\subsection{The OTA Production Effected by High Concentration of $\mathrm{NaCl}$ or Glucose}

Low-concentration $\mathrm{NaCl}$ had a promoting effect on the capacity of OTA production by A. ochraceus fc-1 (Figure 4A). When $20 \mathrm{~g} / \mathrm{L} \mathrm{NaCl}$ was added, OTA production was significantly increased, which was $72.7 \%$ more than that of the control group in the absence of $\mathrm{NaCl}$. When $40 \mathrm{~g} / \mathrm{L} \mathrm{NaCl}$ was added, OTA production decreased, which was $73.6 \%$ lower than that of the control group without $\mathrm{NaCl}$. 
When $60 \mathrm{~g} / \mathrm{L} \mathrm{NaCl}$ was added, trace OTA could be detected; OTA could not be detected at $80 \mathrm{~g} / \mathrm{L} \mathrm{NaCl}$ or higher (Figure $4 \mathrm{~A}$ ).

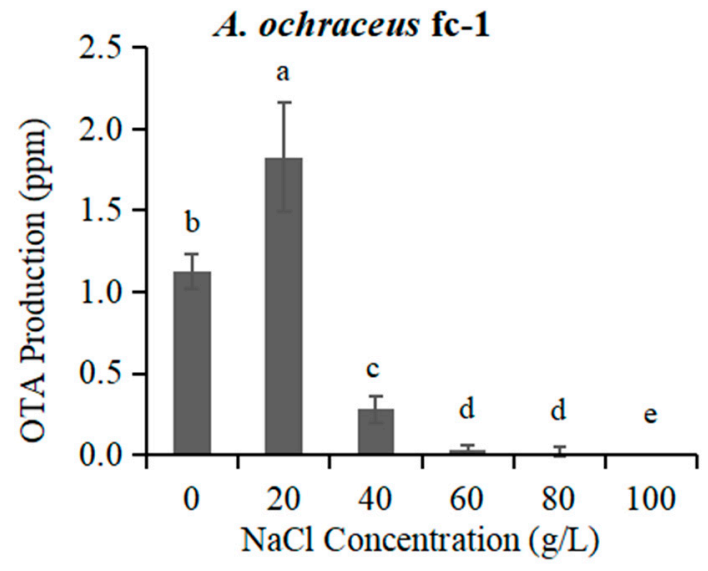

(A)

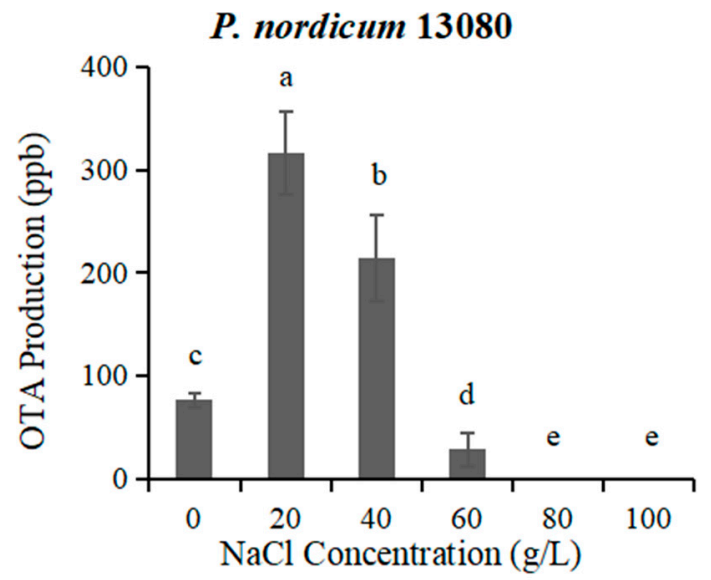

(C)

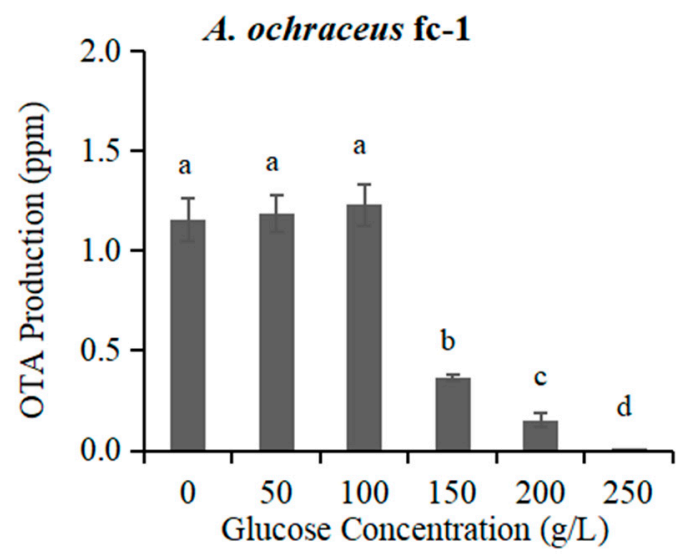

(B)

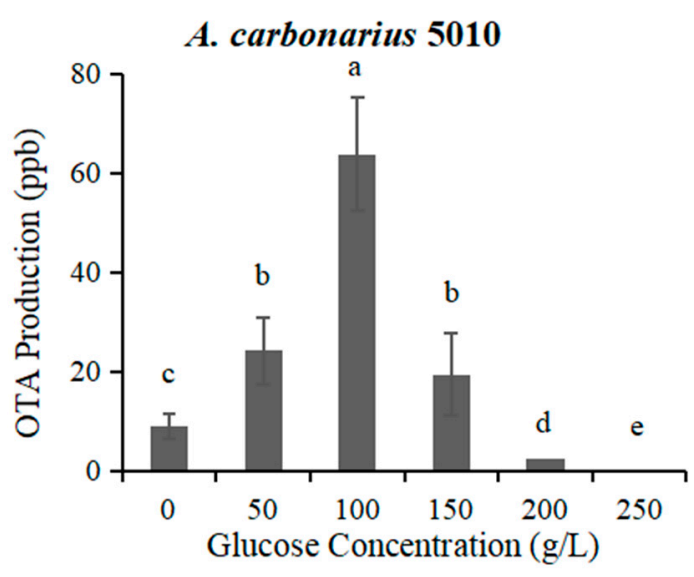

(D)

Figure 4. The Ochratoxin A (OTA) production of A. ochraceus fc-1, A. carbonarius 5010 and P. nordicum 13080 after 5 days of incubation. (A) The OTA production of $A$. ochraceus fc-1grown on NaCl-supplemented PDA plates; (B) The OTA production of A. ochraceus fc-1grown on glucose-supplemented PDA plates; (C) The OTA production of $P$. nordicum 13080 grown on NaCl-supplemented MEA plates; (D) The OTA production of A. carbonarius 5010 grown on glucose-supplemented YES plates. Different letters indicate a significant difference between the corresponding values $(p<0.05)$.

Low-concentration glucose $(0-100 \mathrm{~g} / \mathrm{L})$ had almost no effect on the capacity of OTA production (Figure 4B). With the addition of $150 \mathrm{~g} / \mathrm{L}$ glucose, the OTA yield decreased, which was 65.0\% lower than that of the control group without glucose. With the addition of $250 \mathrm{~g} / \mathrm{L}$ glucose, the OTA yield was very low, $0.5 \%$ of the control group in absence of glucose (Figure $4 \mathrm{~B}$ ).

Similar with A. ochraceus fc-1, the capacity of OTA production by P. nordicum 13080 was increased and then decreased as the $\mathrm{NaCl}$ concentration increased (Figure 4C). When $20 \mathrm{~g} / \mathrm{L} \mathrm{NaCl}$ was added, the capacity of OTA production was 4.1 times higher than that of the control group. Compared to A. ochraceus fc-1, the capacity of OTA production by P. nordicum 13080 was still increased, and 2.8 times higher than that of the control group, when the addition was of $40 \mathrm{~g} / \mathrm{L} \mathrm{NaCl}$. OTA could not be detected at $80 \mathrm{~g} / \mathrm{L} \mathrm{NaCl}$ or higher (Figure $4 \mathrm{C}$ ).

Different from the tendency of OTA production in A. ochraceus fc-1, the capacity of OTA production by $A$. carbonarius 5010 was increased and then decreased as the glucose concentration increased 
(Figure 4D). With the addition of glucose at 0-150 g/L, the OTA production was higher than that of control group. When $100 \mathrm{~g} / \mathrm{L}$ glucose was added, the capacity of OTA production was 7.1 times higher than that of control group. When $200 \mathrm{~g} / \mathrm{L}$ glucose was added, trace OTA could be detected; OTA could not be detected at $250 \mathrm{~g} / \mathrm{L}$ glucose (Figure 4D).

\subsection{Relationship between Water Activity (Ionic Concentration) and OTA Production}

With the addition of $\mathrm{NaCl}$ or glucose, the water activity decreased gradually, and the water activity was negatively correlated with ion concentration. The water activity of the medium with a salinity of 0 , $20,40,60,80$ and $100 \mathrm{~g} / \mathrm{L}$ was $0.991,0.975,0.962,0.950,0.934$ and 0.929 , respectively. The water activity of the medium containing $0,50,100,150,200$ and $250 \mathrm{~g} / \mathrm{L}$ glucose was $0.991,0.992,0.988,0.981,0.971$ and 0.965 , respectively. Pearson's correlation coefficient $\left(\mathrm{R}^{2}\right)$ was used to assess the correlation between water activity and ion concentration. A high Pearson's correlation coefficient $\mathrm{R}^{2}=0.993(p<0.01)$ and $\mathrm{R}^{2}=0.956(p<0.01)$ was found between water activity and ionic concentration $(\mathrm{NaCl}, \mathrm{glucose})$, indicating that the water activity was closely correlated with ionic concentration.

Further, the relationship of OTA production with ionic concentration, water activity, colony diameter, and spore number in A. ochraceus, $A$. carbonarius, and $P$. nordicum were analyzed. The correlation was only observed between glucose concentration and spore number in $A$. ochraceus $\left(\mathrm{R}^{2}=0.993, p<0.05\right)$, between $\mathrm{NaCl}$ concentration and spore number in P. nordicum $\left(\mathrm{R}^{2}=0.899, p<0.05\right)$. The ionic concentration was not significantly associated with fungi growth and OTA production.

\subsection{The Expression of OTA Biosynthetic Genes Effected by the Addition of $\mathrm{NaCl}$ or Glucose}

The expression of OTA biosynthetic genes $(\operatorname{ota} A-D)$ and regulatory genes (otaR1) were detected by qRT-PCR. OTA biosynthesis begins with a polyketide synthase, OtaA, utilizing acetyl-CoA and malonyl-CoA to synthesize 7-methylmellein, which is a speed-limiting step of the synthesis of OTA. The transcriptional expression level of AootaA was increased 10.5 times in A. ochraceus at mediun supplied with $20 \mathrm{~g} / \mathrm{L} \mathrm{NaCl}$, the PnotaA gene expression was up regulated 33.0 times in $P$. nordicum at mediun supplied with $20 \mathrm{~g} / \mathrm{L} \mathrm{NaCl}$ (Figure 5A). When $70 \mathrm{~g} / \mathrm{L} \mathrm{NaCl}$ was added, the expression level of Aoota $A$ was 0.4 times lower than that of the control group without $\mathrm{NaCl}$ (Figure $5 \mathrm{~A}$ ). With the addition of $100 \mathrm{~g} / \mathrm{L}, 250 \mathrm{~g} / \mathrm{L}$ glucose, the expression level of AootaA was 1.5 and 1.7 times that of the control group without glucose, respectively (Figure 5B). The AcotaA gene expression was up regulated 3.5 times in $A$. carbonarius at mediun supplied with $100 \mathrm{~g} / \mathrm{L}$ glucose, and down regulated 0.3 times in medium supplied with $250 \mathrm{~g} / \mathrm{L}$ glucose.

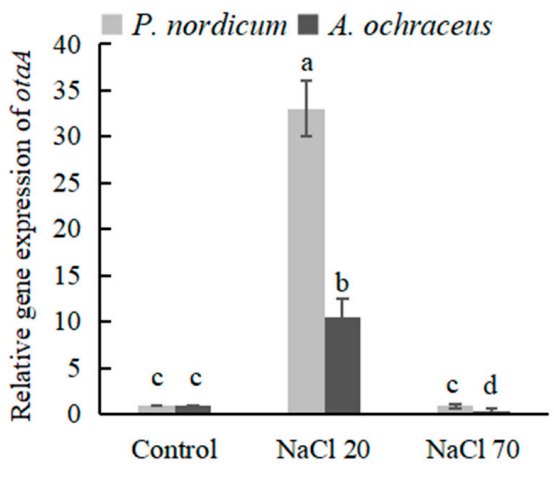

(A)

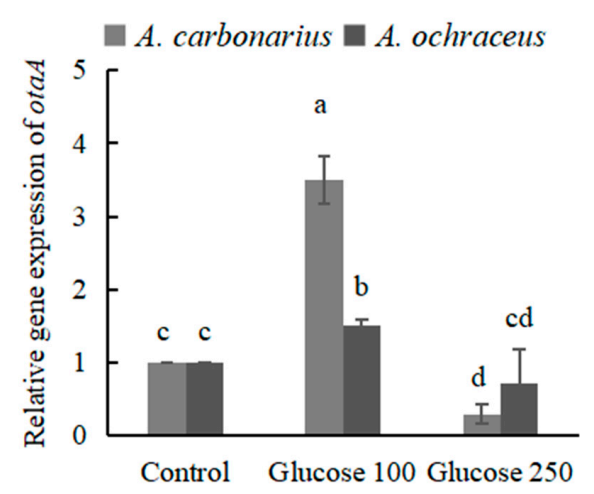

(B)

Figure 5. The relative expression level of OTA biosynthetic genes AootaA in A. ochraceus fc-1, AcotaA in A. carbonarius 5010 and PnotaA in P. nordicum 13080 at high osmotic conditions after 5 days of incubation. (A) The relative expression level of otaA on $\mathrm{NaCl}$-supplemented medium; (B) The relative expression level of otaA on glucose-supplemented medium. Different letters indicate a significant difference between the corresponding values $(p<0.05)$. 
With the addition of $100 \mathrm{~g} / \mathrm{L}, 250 \mathrm{~g} / \mathrm{L}$ glucose, the expression level of AootaB was 2.1 and 2.8 times higher than that of the control group without glucose, respectively (Figure 6A), but the expression level of AootaC was 0.2 and 0.06 times lower than that of the control group without glucose, respectively (Figure 6B). The expression level of AootaA, AootaD and AootaR1 was increased 1.5, 1.0, and 1.3 times higher in A. ochraceus at mediun supplied with $100 \mathrm{~g} / \mathrm{L}$ glucose than that of the control group without glucose (Figures 5B and 6C,D), and decreased 0.7, 0.8, and 0.4 times lower in A. ochraceus at mediun supplied with $250 \mathrm{~g} / \mathrm{L}$ glucose than that of the control group without glucose (Figures 5B and 6C,D).

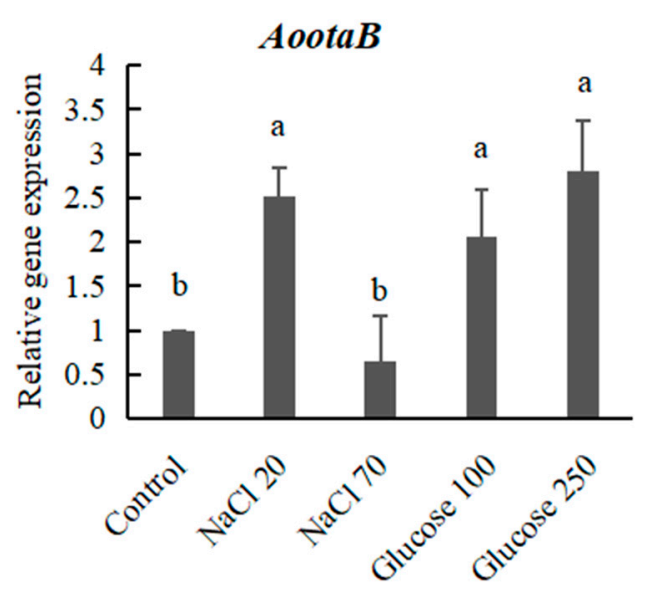

(A)

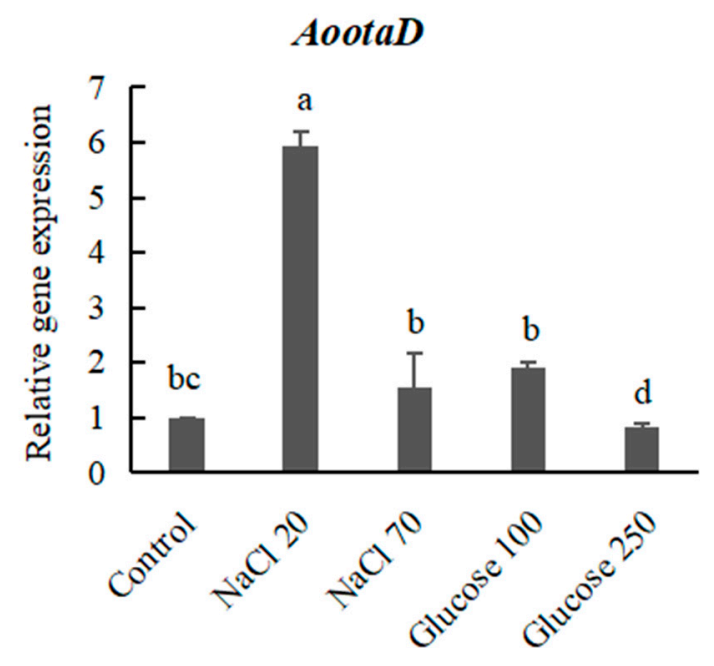

(C)

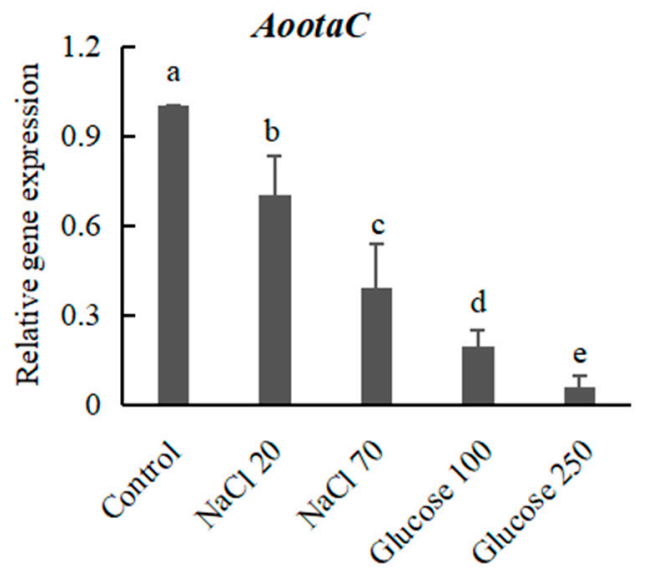

(B)

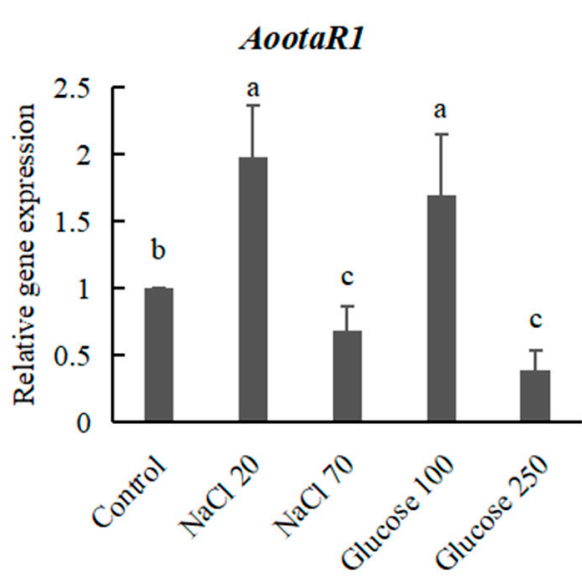

(D)

Figure 6. The relative expression level of OTA biosynthetic genes AootaB (A), AootaC (B) and AootaD (C), and regulatory gene AootaR1 (D) in A. ochraceus fc- 1 at high osmotic conditions after 5 days of incubation. Different letters indicate a significant difference between the corresponding values $(p<0.05)$.

\section{Discussion}

Different from other mycotoxins (aflatoxin, fumonisin, deoxynivalenol, zearalenone), ochratoxins are mainly produced by some species in Aspergillus and Penicillium. Until now, more than 20 species of toxigenic fungi are found to produce ochratoxins, which contaminate different foodstuffs depending on different temperature, humidity and other climatic conditions [2]. OTA could not only be detected in high sugar and low pH-fruits, such as grape and berry [6,7], but also in $\mathrm{NaCl}$ and protein rich dry-cured meats and cheeses [12,16,17]. In 2012, the positive rate of OTA in dried vine fruits collected in a Chinese market was $58.9 \%$, with a mean level of $0.99 \mu \mathrm{g} / \mathrm{kg}$ [18]. In 2016, of 30 commercial 
samples of dried vine fruits analyzed, 10 were contaminated with ochratoxins, and OTA-related metabolites ochratoxin alpha (OT $\alpha)$, ochratoxin B (OTB) and mellein were also detected in different samples [19]. In 2018, the positive rate of OTA in 172 salami samples collected in four regions of Italy was $12.8 \%$ [20]. Mycotoxins are secondary metabolites of fungi, and their biological functions are related to the adaptation of fungi to the survival environment (food medium) [21], just like OTA is supportive for growth in high salt environments in Penicillium spp., but the biological function of OTA is unclear in Aspergillus spp. [15,22].

In fungi, the biosynthesis of ochratoxin A plays an adaptive role in certain food environments. There is a need to understand the mechanism of adaptation of toxigenic fungal species, which are able to colonize highly specialized foods such as cured meats, where there is a high osmotic stress due to the presence of up to $20-22 \% \mathrm{NaCl}$ during the ripening process [23]. A. ochraceus fc- 1 and $P$. nordicum 13080 were likely to have greater growth rates in medium supplied with $40 \mathrm{~g} / \mathrm{L} \mathrm{NaCl}$, compared with no $\mathrm{NaCl}$ addition. When $80 \mathrm{~g} / \mathrm{L} \mathrm{NaCl}$ was added, it would always slightly promote the growth of mycelium. Different from mycelium growth, both fungi were likely to produce high levels of OTA in medium supplied with $20 \mathrm{~g} / \mathrm{L} \mathrm{NaCl}$. In particular, P. nordicum 13080 was more suitable to grow in $\mathrm{NaCl}$ concentrated medium, and the capability of OTA production was stronger than A. ochraceus fc-1; the OTA production was increased to $316 \mathrm{ppb}$ from $77 \mathrm{ppb}$ when $20 \mathrm{~g} / \mathrm{L} \mathrm{NaCl}$ was added. P. nordicum is able to successfully adapt to the characteristic $\mathrm{NaCl}$-rich environment of the dry-cured meat products, and OTA is frequently detected in dry-cured meat products $[10,20]$. Due to different percentages of $\mathrm{NaCl}$ added in ripening processing technology, the period of logarithmic growth and OTA yield varies among different fungi in sausage products [24]. Both fungi were more tolerant at moderate ionic $\mathrm{a}_{\mathrm{w}}$ conditions (0.93 to 0.99$)$ under $28^{\circ} \mathrm{C}$, and the growth of fungi were promoted in medium supplied with certain concentrations of $\mathrm{NaCl}$. Nevertheless, the ionic $\mathrm{a}_{\mathrm{w}}$ circumstances of production of OTA were very different from those for growth. Different OTA production profiles between the two OTA-producing species were found. OTA biosynthesis gene cluster is the same among these OTA-producing fungi, while the adaptability of the strains to ionic concentration, and the selectivity of strains to host or carbon source are different. The OTA contamination by P. nordicum in ham-based media is affected by ionic $\mathrm{a}_{\mathrm{w}}(\mathrm{NaCl})$, a moderate correlation is found between OTA biosynthetic genes and OTA yield and the activation of biosynthetic genes of P. nordicum is earlier than OTA detection [23].

The temporal changes in the expression of the OtaA gene by A. ochraceus and P. nordicum are related to OTA production on medium supplied with certain concentrations of $\mathrm{NaCl}$. The OtaA gene was overexpressed by both fungi in medium supplied with $20 \mathrm{~g} / \mathrm{L} \mathrm{NaCl}$, especially in P. nordicum. Gene expression was higher in P. nordicum than in $A$. ochraceus in medium supplied with $20 \mathrm{~g} / \mathrm{L} \mathrm{NaCl}$ (Figure 5A). The high significant correlation was found between the early relative expression of the OtaA (otapks) gene and OTA production in P. nordicum [25]. Low-concentration $\mathrm{NaCl}$ could promote the expression of the OTA biosynthetic genes, while high-concentration $\mathrm{NaCl}$ could inhibit gene expression. The chloride ion is related to the substitution reaction catalyzed by halogenase OtaD in the OTA biosynthesis pathway [13,14], and the expression level of the AootaD gene is still up-regulated in high-salt medium (Figure 6C).

Except the $\mathrm{NaCl}$-rich food environment, most aspergilli can be isolated from a wide range of products, including cereals, cocoa, coffee, dried fruits, raisins, wine, etc [26]. In particular, $A$. carbonarius are considered as the main source of OTA contamination in grapes, figs, berries and related juice products [27]. The optimum values for growth of $A$. carbonarius on a grape juice-based medium were observed at $30-35{ }^{\circ} \mathrm{C}$ and $0.96 \mathrm{a}_{\mathrm{w}}$, while for OTA production at $20^{\circ} \mathrm{C}$ and $0.98 \mathrm{a}_{\mathrm{w}}$ [26]. The sugar content of wine grapes is between $22 \%$ and $30 \%$, while eating grapes may be closer to $10-15 \%$. The sugar content of raisins is very high, up to $10 \sim 30 \%$, and glucose is predominant. The sugar content of grape juice is about $200 \mathrm{~g} / \mathrm{L}$. At the drying stage, grapes are dried until they reach the desired sugar content, around $300 \mathrm{~g} / \mathrm{L}$, and $\mathrm{a}_{\mathrm{w}}$ values decrease from 0.95 to $0.75 \mathrm{a}_{\mathrm{w}}[28,29]$. As a result of the increase in black aspergilli during this sun-dried period, high levels of OTA are present in wines produced from dehydrated grapes [29]. As the glucose concentration increases to the highest concentration 
( $250 \mathrm{~g} / \mathrm{L}$ glucose), there is a tendency for the growth rate to increase in both species, A. ochraceus and $A$. carbonarius. OTA production is promoted with added glucose and a certain concentration of glucose $(100 \mathrm{~g} / \mathrm{L})$ induces significant OTA production in A. carbonarius (Figure $4 \mathrm{D})$. Glucose can not promote OTA production in A. ochraceus, on the contrary, OTA production is inhibited under high glucose concentration $(150 \mathrm{~g} / \mathrm{L})$; as a result, the $\mathrm{a}_{\mathrm{w}}$ values decrease to 0.96 (Figure $\left.4 \mathrm{~B}\right)$. The expression of the OtaA (AcOTApks) was monitored at the same time points along with fungal biomass and OTA accumulation in A. carbonarius 5010; the phenomenon was consistent with P. nordicum, activation of the biosynthetic genes OtaA that was observed a few days before ochratoxin A could be detected [30]. The ot $A$ A gene was overexpressed by both fungi in medium supplied with $100 \mathrm{~g} / \mathrm{L}$ glucose, especially in A. carbonarius (Figure 5B). The expression of AootaC was down-regulated; that could be one reason that the OTA accumulation in A. ochraceus supplied with glucose was not increased.

\section{Conclusions}

The results of this study showed the relationship between salt/sugar content and fungal colonization and OTA accumulation. The most powerful strategy to control OTA contamination in cereal, grape related products and dry-cured meat products is the prevention of mycotoxigenic. The mycelium growth was inhibited significantly when salt content reached $100 \mathrm{~g} / \mathrm{L}$, and the capacity of sporulation was decreased enormously when salt content was greater than $60 \mathrm{~g} / \mathrm{L}$ and $80 \mathrm{~g} / \mathrm{L}$ in A. ochraceus and P. nordicum. Meanwhile, OTA production was inhibited when salt content was greater than $40 \mathrm{~g} / \mathrm{L}$ and $60 \mathrm{~g} / \mathrm{L}$ in A. ochraceus and P. nordicum, respectively. The addition of glucose (until $250 \mathrm{~g} / \mathrm{L}$ ) could not inhibit mycelium growth and sporulation, and OTA production was inhibited when glucose content was greater than $150 \mathrm{~g} / \mathrm{L}$ and $200 \mathrm{~g} / \mathrm{L}$ in A. ochraceus and A. carbonarius, respectively. The genes involved in the OTA biosynthetic pathway and the positive and negative effects of the osmolytes on their expressions are summarized in Table 1. By controlling $\mathrm{NaCl}$ addition, the content of glucose concentration and monitoring the expression of toxigenic genes, the colonization and toxin production was remarkably reduced.

Table 1. The positive and negative effects of osmotic pressure on OTA biosynthetic genes expression.

\begin{tabular}{|c|c|c|c|c|c|c|c|c|c|}
\hline \multirow{3}{*}{ Genes } & \multirow{3}{*}{ Functions } & \multirow{2}{*}{\multicolumn{2}{|c|}{$\begin{array}{c}\text { P. nordicum } \\
\mathrm{NaCl}(\mathrm{g} / \mathrm{L})\end{array}$}} & \multicolumn{4}{|c|}{ A. ochraceus } & \multirow{2}{*}{\multicolumn{2}{|c|}{$\begin{array}{c}\text { A. carbonarius } \\
\text { Glc }(\mathrm{g} / \mathrm{L})\end{array}$}} \\
\hline & & & & \multicolumn{2}{|c|}{$\mathrm{NaCl}(\mathrm{g} / \mathrm{L})$} & \multicolumn{2}{|c|}{ Glc $(g / L)$} & & \\
\hline & & 20 & 70 & 20 & 70 & 100 & 250 & 100 & 250 \\
\hline otaA & type i iterative polyketide synthase (PKS) & + & $\mathrm{N}$ & + & - & + & $\mathrm{N}$ & + & - \\
\hline$o t a B$ & nonribosomal peptide synthase (NRPS) & & & + & $\mathrm{N}$ & + & + & & \\
\hline otaC & cytochrome p450 monooxygenase & & & - & - & - & - & & \\
\hline otaD & halogenase & & & + & + & + & - & & \\
\hline otaR1 & bZIP transcription factor & & & + & - & + & - & & \\
\hline
\end{tabular}

Note: "+" indicates up regulated significantly, "-" indicates down regulated significantly, " $\mathrm{N}$ " indicates no significant change.

\section{Materials and Methods}

\subsection{Strains and Media}

A. ochraceus fc-1 was isolated and characterized in our laboratory [13]. A. carbonarius 5010 was given by Prof. Dr. Angelo Visconti and Dr. Giancarlo Perrone. P. nordicum 13080 was obtained from the Institute of Sciences of Food Production "Agro-Food Microbial Culture Collection-ITEM", Italy. These strains were routinely cultured on Potato Dextrose Agar (PDA, Potato $200 \mathrm{~g} / \mathrm{L}$; glucose $20 \mathrm{~g} / \mathrm{L}$; agar $20 \mathrm{~g} / \mathrm{L}$ ) for 7 days at $28^{\circ} \mathrm{C}$ in dark conditions. Conidia from cultures were obtained by scraping them from PDA plates with a sterile cotton swab, and resuspended in sterile water. The conidia count was adjusted to $10^{7}$ conidia/mL using a haematocytometer. The strains were maintained as conidial suspensions and stored at $-80{ }^{\circ} \mathrm{C}$ with $15 \%$ glycerol and new cultures were used for each experiment [31]. 


\subsection{Culture Media Preparation and Culture Conditions}

Concentrations of $0,20,40,60,80,100 \mathrm{~g} / \mathrm{L} \mathrm{NaCl}$ or $0,50,100,150,200,250 \mathrm{~g} / \mathrm{L}$ glucose were added to PDA medium, and the culture media were prepared by autoclaving for $20 \mathrm{~min}$ at $121^{\circ} \mathrm{C}$. A. ochraceus fc- 1 was cultured at $28^{\circ} \mathrm{C}$ for 7 days. A. carbonarius 5010 was grown on Yeast Extract Sucrose Agar (YES, yeast extract $20 \mathrm{~g} / \mathrm{L}$, sucrose $150 \mathrm{~g} / \mathrm{L}$, agar $15 \mathrm{~g} / \mathrm{L}$ ) supplemented with different amounts of glucose $(0,50,100,150,200,250 \mathrm{~g} / \mathrm{L})$, cultured at $28^{\circ} \mathrm{C}$ for 7 days; P. nordicum 13080 was grown on Malt Extract Agar (MEA, malt extract $30 \mathrm{~g} / \mathrm{L}$, soy peptone $3 \mathrm{~g} / \mathrm{L}$, agar $15 \mathrm{~g} / \mathrm{L}$ ) medium supplemented with different amounts of $\mathrm{NaCl}(0,20,40,60,80,100 \mathrm{~g} / \mathrm{L})$, cultured at $28^{\circ} \mathrm{C}$ for 7 days.

\subsection{Mycelial Growth Rate and Conidia Count}

The mycelial growth of $A$. ochraceus fc-1 was evaluated according to [15], with modifications. For analyses of the diameters of the colonies, $5 \mu \mathrm{L}$ of the $10^{7}$ conidia $\mathrm{mL}^{-1}$ suspension was added dropwise to the center of the solid medium. The colony growth diameter was measured every $12 \mathrm{~h}$ using a cross method. Data were analysed using a primary model by plotting colony diameter against time. Data plots showed, after a lag phase, a linear trend with time. The linear part of this graph (linear phase) was used to calculate growth rate ( $\mathrm{mm} /$ day) [10]. All experiments were done with three replicates per treatment and repeated twice.

The percentage of mycelial growth inhibition was calculated according to the following formula: Inhibition $(\%)=[(\mathrm{C}-\mathrm{T}) / \mathrm{C}] \times 100 \%$, where $\mathrm{C}$ is the mean colony diameter for the controls and $\mathrm{T}$ is the mean colony diameter for each group treated with $\mathrm{NaCl}$ or glucose.

Five agar plugs (diameter $8 \mathrm{~mm}$ ) were taken from the colony, transferred into $10 \mathrm{~mL}$ micro reaction tubes, and $5 \mathrm{~mL}$ of sterile water containing $0.01 \%$ Tween 80 was added. The spore were dissolved for $2 \mathrm{~h}$ at room temperature on a rotary shaker and the amount of conidia was counted using a haemocytometer (Fisher Scientific, Loughborough, UK). All experiments were done with three replicates per treatment and repeated twice.

\subsection{Extraction and Quantification of OTA}

For determination of Ochratoxin A production, the strains were grown at $28{ }^{\circ} \mathrm{C}$ on $\mathrm{NaCl}$ or glucose supplemented agar plates. Five agar plugs (diameter $8 \mathrm{~mm}$ ) were taken from the colony, transferred into $2 \mathrm{~mL}$ micro reaction tubes and $1 \mathrm{~mL}$ of methanol was added. The fungal mycelia were extracted for $2 \mathrm{~h}$ at room temperature on a rotary shaker; the mycelia were discarded and the supernatant were filtered through a $0.22 \mu \mathrm{m}$ filter into the brown vials [31].

The HPLC equipment consisted of an Agilent 1260 series system (Agilent, Berks., UK) with a fluorescence detector and an autosampler. Analysis was done in the isocratic mode and the mobile phase was acetonitrile: water: acetic acid (99:99:2 v/v/v) at a flow rate of $1 \mathrm{~mL} / \mathrm{min}$. The injection volume was $20 \mu \mathrm{L}$. FLD detection was performed at an excitation wavelength of $330 \mathrm{~nm}$ and an emission wavelength of $460 \mathrm{~nm}$, using a C18 column $(150 \mathrm{~mm} \times 4.6 \mathrm{~mm}, 5 \mu \mathrm{m})$. Pure ochratoxin A (Sigma, St. Louis, MO, USA) was used as standard [31].

\subsection{Gene Expression Studies}

In order to determine the expression of OTA biosynthesis, genes under different high osmotic conditions, A. ochraceus fc- 1 , A. carbonarius 5010 and P. nordicum 13080, were cultivated in NaCl- or glucose-supplied media for 5 days at $28^{\circ} \mathrm{C}$ in dark. The mycelium used for this assay was collected, dipped in liquid nitrogen immediately for pre-cooling and stored at $-80^{\circ} \mathrm{C}$ before use. Total RNA was extracted using the RNeasy Plant Mini Kit (QIAGEN, Germany). An amount of $1.0 \mathrm{~g}$ of the mycelium was ground in a mortar in the presence of liquid nitrogen. RNA concentration was determined by a Nanodrop Lite spectrophotometer (Thermo Scientific, Waltham, MA, USA). Reverse Transcription PCR (RT-qPCR) was carried out by using the RNA PCR Kit (AMV) (TAKARA, Otsu, Shiga, Japan) [31]. Specific primers used for RT-qPCR were listed in Table 2. The RT-qPCR was reacted using SYBR Green PCR Master Mix 
and performed in a 7500 Real-Time PCR system (Applied Biosystems, Foster City, CA, USA). The thermal protocol was conducted as described previously [13]. The relative gene expression was calculated with the internal control, and the relative quantification of the target gene expression was calculated according to the method of $2^{-\Delta \Delta C T}$, where $\Delta \Delta \mathrm{C}_{\mathrm{T}}=\left(\mathrm{C}_{\mathrm{T} \text {, Target }}-\mathrm{C}_{\mathrm{T} \text {, Ref }}\right)_{\text {Treatment }}-\left(\mathrm{C}_{\mathrm{T} \text {, Target }}-\mathrm{C}_{\mathrm{T} \text {, Ref }}\right)_{\text {Control }}$.

Table 2. Nucleotide sequences of primers for real time PCR assays.

\begin{tabular}{|c|c|c|}
\hline Primer Name & Sequence $\left(5^{\prime}\right.$ to $\left.3^{\prime}\right)$ & Strain \\
\hline GADPH-F & TGCTCAAGTACGACAGCACC & \multirow{12}{*}{ Aspergillus ochraceus [13] } \\
\hline GADPH-R & CTCGGCGAAGAACTGAACCT & \\
\hline AootaA-F & CGCСТCАTCATCAATCСТT & \\
\hline AootaA-R & CAACTCGGTCAAGCAGAT & \\
\hline AootaB-F & ATACCACCAGAGCTCCAAA & \\
\hline AootaB-R & GAGATGTTCGGTCTGTTCA & \\
\hline AootaC-F & CTTAATACGGTGGTCTACGA & \\
\hline AootaC-R & GAATGATAGGTCCGTATTTCT & \\
\hline AootaD-F & CTATCCGGTGGTCTGTCAGC & \\
\hline AootaD-R & TGAATGCATCGTCGAACCCA & \\
\hline AootaR1-F & GCTTTCAAATCGAATGATTCC & \\
\hline AootaR1-R & GATCGGTTGGAAGTGTAGAA & \\
\hline$\beta-t u b \mathrm{~F}$ & GCCAGCGGTGACAAGTACGT & \multirow{4}{*}{ Penicillium nordicum [10] } \\
\hline$\beta-t u b \mathrm{R}$ & TACCGGGCTCCAAATCGA & \\
\hline PnotaA-F & CGCCGCTGCGGTTACT & \\
\hline PnotaA-R & GGTAACAATCAACGCTCCСТCTT & \\
\hline$\beta-t u b \mathrm{~F}$ & CAAACCGGCCAGTGTGGTA & \multirow{4}{*}{ Aspergillus carbonarius [32] } \\
\hline$\beta$-tub R & CGGAGGTGCCATTGTAAACA & \\
\hline AcotaA-F & CGTGTCCGATACTGTCTGTGA & \\
\hline$A \cot a A-\mathrm{R}$ & GCATGGAGTCCTCAAGAACC & \\
\hline
\end{tabular}

\subsection{Data Analysis}

All the statistical analyses were performed by Microsoft Excel 2013 and SPSS Statistics 21.0. The gene expression analyses were evaluated using one-way analysis of variance (ANOVA). Mean comparison was analyzed through Duncan's multiple-range test. Differences were considered to be significant at $p<0.05$. Pearson's correlation analysis between water activity and ion concentration was performed by SPSS Statistics 21.0 (IBM, Armonk, NY, USA). Pearson's correlation coefficient $\left(\mathrm{R}^{2}\right)$ was used to assess the correlation between water activity and ion concentration.

Author Contributions: Conceptualization, Y.W. and H.Y.; methodology, Y.W.; formal analysis, J.G. and B.Y.; validation, H.Y.; writing — original draft preparation, J.G. and Y.W.; writing —review and editing, J.N. and Y.W.; project administration, Y.W. and Y.L.; funding acquisition, Y.W. and Y.L. All authors have read and agreed to the published version of the manuscript.

Funding: This research was funded by the Youth Program of the National Natural Science Foundation of China (31601577), the National Key Research and Development Program of China (2017YFC1600904, 2019YFC1604500) and the Central Public-interest Scientific Institution Basal Research Fund (2019).

Acknowledgments: The authors would like to acknowledge Angelo Visconti and Giancarlo Perrone for A. carbonarius 5010 used in the experiments.

Conflicts of Interest: The authors declare no competing financial interest.

\section{References}

1. Ostry, V.; Malir, F.; Ruprich, J. Producers and important dietary sources of ochratoxin A and citrinin. Toxins 2013, 5, 1574-1586. [CrossRef] [PubMed]

2. Wang, Y.; Wang, L.; Liu, F.; Wang, Q.; Selvaraj, J.N.; Xing, F.; Zhao, Y.; Liu, Y. Ochratoxin A producing fungi, biosynthetic pathway and regulatory mechanisms. Toxins 2016, 8, 83. [CrossRef] [PubMed]

3. Zhao, T.; Shen, X.L.; Chen, W.; Liao, X.; Yang, J.; Wang, Y.; Zou, Y.; Fang, C. Advances in research of nephrotoxicity and toxic antagonism of Ochratoxin A. Toxin Rev. 2017, 36, 39-44. [CrossRef] 
4. Northolt, M.D.; Van Egmond, H.P.; Paulsch, W.E. Ochratoxin A production by some fungal species in relation to water activity and temperature. J. Food Prot. 1979, 42, 485-490. [CrossRef] [PubMed]

5. Ramos, A.J.; Labernia, N.; Marín, S.; Sanchis, V.; Magan, N. Effect of water activity and temperature on growth and ochratoxin production by three strains of Aspergillus ochraceus on a barley extract medium and on barley grains. Int. J. Food Microbiol. 1998, 44, 133-140. [CrossRef]

6. Somma, S.; Perrone, G.; Logrieco, A.F. Diversity of black Aspergilli and mycotoxin risks in grape, wine and dried vine fruits. Phytopathol. Mediterr. 2012, 51, 131-147.

7. Cervini, C.; Gallo, A.; Piemontese, L.; Magistà, D.; Logrieco, A.F.; Ferrara, M.; Solfrizzo, M.; Perrone, G. Effects of temperature and water activity change on ecophysiology of ochratoxigenic Aspergillus carbonarius in field-simulating conditions. Int. J. Food Microbiol. 2020, 315, 108420. [CrossRef]

8. Bejaoui, H.; Mathieu, F.; Taillandier, P.; Lebrihi, A. Black aspergilli and ochratoxin A production in French vineyards. Int. J. Food Microbiol. 2006, 111 (Suppl. S1), 46-52. [CrossRef]

9. Zadravec, M.; Vahčić, N.; Brnić, D.; Markov, K.; Frece, J.; Beck, R.; Lešić, T.; Pleadin, J. A study of surface moulds and mycotoxins in Croatian traditional dry-cured meat products. Int. J. Food Microbiol. 2020, 317, 108459. [CrossRef]

10. Delgado, J.; da Cruz Cabral, L.; Rodríguez, A.; Rodríguez, M. Influence of ochratoxin A on adaptation of Penicillium nordicum on a NaCl-rich dry-cured ham-based medium. Int. J. Food Microbiol. 2018, 272, $22-28$. [CrossRef]

11. Jiang, C.; Shi, J.; Zhu, C. Fruit spoilage and ochratoxin a production by Aspergillus carbonarius in the berries of different grape cultivars. Food Control 2013, 30, 93-100. [CrossRef]

12. Merla, C.; Andreoli, G.; Garino, C.; Vicari, N.; Tosi, G.; Guglielminetti, M.L.; Moretti, A.; Biancardi, A.; Arlorio, M.; Fabbi, M. Monitoring of ochratoxin A and ochratoxin-producing fungi in traditional salami manufactured in Northern Italy. Mycotoxin Res. 2018, 34, 107-116. [CrossRef]

13. Wang, Y.; Wang, L.; Wu, F.; Liu, F.; Wang, Q.; Zhang, X.; Selvaraj, J.N.; Zhao, Y.; Xing, F.; Yin, W.-B.; et al. A consensus ochratoxin A biosynthetic pathway: Insights from the genome sequence of Aspergillus ochraceus and a comparative genomic analysis. Appl. Environ. Microbiol. 2018, 84, e01009-18. [CrossRef] [PubMed]

14. Ferrara, M.; Perrone, G.; Gambacorta, L.; Epifani, F.; Solfrizzo, M.; Gallo, A. Identification of a halogenase involved in the biosynthesis of ochratoxin A in Aspergillus carbonarius. Appl. Environ. Microbiol. 2016, 82, 5631-5641. [CrossRef] [PubMed]

15. Schmidt-Heydt, M.; Graf, E.; Stoll, D.; Geisen, R. The biosynthesis of ochratoxin A by Penicillium as one mechanism for adaptation to $\mathrm{NaCl}$ rich foods. Food Microbiol. 2012, 29, 233-241. [CrossRef] [PubMed]

16. Ferrara, M.; Magistà, D.; Lippolis, V.; Cervellieri, S.; Susca, A.; Perrone, G. Effect of Penicillium nordicum contamination rates on ochratoxin A accumulation in dry-cured salami. Food Control 2016, 67, 235-239. [CrossRef]

17. Coton, M.; Coton, E.; Auffret, A.; Poirier, E.; Debaets, S.; Dantigny, P. Production and migration of ochratoxin A and citrinin in Comté cheese by an isolate of Penicillium verrucosum selected among Penicillium spp. mycotoxin producers in YES medium. Food Microbiol. 2019, 82, 551-559. [CrossRef]

18. Zhang, X.; Li, J.; Zong, N.; Zhou, Z.; Ma, L. Ochratoxin A in dried vine fruits from Chinese markets. Food Addit. Contam. Part B 2014, 7, 157-161. [CrossRef]

19. Zhang, X.; Li, J.; Cheng, Z.; Zhou, Z.; Ma, L. High-performance liquid chromatography-tandem mass spectrometry method for simultaneous detection of ochratoxin A and relative metabolites in Aspergillus species and dried vine fruits. Food Addit. Contam. Part A 2016, 33, 1355-1366.

20. Altafini, A.; Fedrizzi, G.; Roncada, P. Occurrence of ochratoxin A in typical salami produced in different regions of Italy. Mycotoxin Res. 2018, 35, 141-148. [CrossRef]

21. Geisen, R.; Touhami, N.; Schmidt-Heydt, M. Mycotoxins as adaptation factors to food related environments. Curr. Opin. Food Sci. 2017, 17, 1-8. [CrossRef]

22. Geisen, R.; Stoll, D.; Schmidt-Heydt, M. Differences in the regulation of ochratoxin a by the HOG pathway in Penicillium and Aspergillus in response to high osmolar environments. Toxins 2013, 5, 1282-1298.

23. Rodríguez, A.; Medina, Á.; Córdoba, J.J.; Magan, N. The influence of salt ( $\mathrm{NaCl})$ on ochratoxin A biosynthetic genes, growth and ochratoxin A production by three strains of Penicillium nordicum on a dry-cured ham-based medium. Int. J. Food Microbiol. 2014, 178, 113-119. [CrossRef] 
24. Rodríguez, A.; Capela, D.; Medina, Á.; Córdoba, J.J.; Magan, N. Relationship between ecophysiological factors, growth and ochratoxin A contamination of dry-cured sausage based matrices. Int. J. Food Microbiol. 2015, 194, 71-77. [CrossRef]

25. Bernáldez, V.; Rodríguez, A.; Delgado, J.; Sánchez-Montero, L.; Córdoba, J.J. Gene expression analysis as a method to predict OTA accumulation in dry-cured meat products. Food Anal. Method 2018, 11, 2463-2471. [CrossRef]

26. Ioannidis, A.-G.; Kogkaki, E.A.; Natskoulis, P.I.; Nychas, G.-J.E.; Panagou, E.Z. Modelling the influence of temperature, water activity and sodium metabisulphite on the growth and OTA production of Aspergillus carbonarius isolated from Greek wine grapes. Food Microbiol. 2015, 49, 12-22. [CrossRef] [PubMed]

27. Valero, A.; Marín, S.; Ramos, A.J.; Sanchis, V. Ochratoxin A-producing species in grapes and sun-dried grapes and their relation to ecophysiological factors. Lett. Appl. Microbiol. 2005, 41, 196-201. [CrossRef] [PubMed]

28. Fodil, S.; Delgado, J.; Varvaro, L.; Yaseen, T.; Rodríguez, A. Effect of potassium sorbate (E-202) and the antifungal PgAFP protein on Aspergillus carbonarius growth and ochratoxin A production in raisin simulating media. J. Sci. Food Agric. 2018, 98, 5785-5794. [CrossRef] [PubMed]

29. Covarelli, L.; Beccari, G.; Marini, A.; Tosi, L. A review on the occurrence and control of ochratoxigenic fungal species and ochratoxin A in dehydrated grapes, non-fortified dessert wines and dried vine fruit in the Mediterranean area. Food Control 2012, 26, 347-356. [CrossRef]

30. Lappa, I.K.; Kizis, D.; Panagou, E.Z. Monitoring the temporal expression of genes involved in ochratoxin a production of Aspergillus carbonarius under the influence of temperature and water activity. Toxins 2017, 9, 296. [CrossRef]

31. Wang, Y.; Liu, F.; Wang, L.; Wang, Q.; Selvaraj, J.N.; Zhao, Y.; Wang, Y.; Xing, F.; Liu, Y. pH-signaling transcription factor AopacC regulates ochratoxin A biosynthesis in Aspergillus ochraceus. J. Agric. Food Chem. 2018, 66, 4394-4401. [CrossRef] [PubMed]

32. Gallo, A.; Knox, B.P.; Bruno, K.S.; Solfrizzo, M.; Baker, S.E.; Perrone, G. Identification and characterization of the polyketide synthase involved in ochratoxin A biosynthesis in Aspergillus carbonarius. Int. J. Food Microbiol. 2014, 179, 10-17. [CrossRef] [PubMed]

(C) 2020 by the authors. Licensee MDPI, Basel, Switzerland. This article is an open access article distributed under the terms and conditions of the Creative Commons Attribution (CC BY) license (http://creativecommons.org/licenses/by/4.0/). 